\title{
PENERAPAN SAKSI TESTIMONIUM DE AUDITU DALAM PERKARA ITSBAT NIKAH DI MAHKAMAH SYAR'IYAH BIREUEN
}

\author{
APPLICATION OF THE DE AUDITU TESTIMONIUM WITNESS IN \\ ITSBAT NIKAH CASE IN MAHKAMAH SYAR'IYAH BIREUEN
}

\author{
Siti Salwa ${ }^{1}$, Yulia $^{2}$, Hamdani $^{3}$ \\ ${ }^{1}$ Mahasiswa Program Studi Magister Hukum Universitas Malikussaleh \\ ${ }^{2,3}$ Dosen Program Magister Ilmu Hukum Universitas Malikussaleh \\ Email: st.salwa@gmail.com
}

\begin{abstract}
This research is motivated by the testimony of testimonium de auditu or istifadhah in the Syar'iyah Bireuen Court, whereas in witness regulations which do not see directly are not justified in civil procedural law, but in the Syar'iyah Bireuen Court it is permissible and uses the witness testimony as a basis for establishing a decision. Based on this description, this study aims to explain the procedure of proving witness testimonium de auditu in the Syar'iyah Bireuen Court in itsbat marriage case and examining the application of witness testimonium de auditu in the marriage itsbat case in the Syar'iyah Bireuen Court. The procedure for evidence of witness testimonium de auditu in the case of marriage law in the Syar'iyah Bireuen Court is the same as the examination of other witnesses. The Syar'iyah Bireuen Court will examine the formal and material requirements to make whether the application is accepted or not. The panel of judges or the presiding judge asks witnesses about their identities which include names, ages, occupations, residences, witness relations with the parties, and whether there is a family, marriage or work relationship, after that everything is checked as usual from the witness oath to witness statements were confirmed in advance to the parties. The application of witness testimonium de auditu in the case of itsbat marriage in the Syar'iyah Bireuen Court is not automatically rejected so that it has no value at all, because it can be accepted as evidence by analyzing the exceptional basis for acceptance by considering the extent to which the quality and value of the strength of the evidence attached to it the de Auditu witness statement, the basis of his acceptance by taking over several sources of law used by the judges in examining and making decisions both in civil law and Islamic law.
\end{abstract}

Keywords: Witness testimonium de Auditu, Itsbat Nikah

\section{Intisari}

Tulisan ini dilatarbelakangi adanya kesaksian testimonium de auditu atau istifadhah di Mahkamah Syar'iyah Bireuen. Dalam peraturan saksi yang tidak melihat secara langsung tidak dibenarkan dalam hukum acara perdata tetapi di Mahkamah Syar'iyah Bireuen dibolehkan dan menggunakan keterangan saksi 
tersebut sebagai landasan untuk menetapkan sebuah putusan. Berdasarkan hal tersebut, penelitian ini bertujuan untuk menjelaskan prosedur pembuktian saksi testimonium de auditu di Mahkamah Syar'iyah Bireuen dalam perkara itsbat nikah dan mengkaji penerapan saksi testimonium de auditu dalam perkara itsbat nikah di Mahkamah Syar'iyah Bireuen. Hasil penelitian, prosedur pembuktian saksi testimonium de auditu dalam perkara itsbat nikah di Mahkamah Syar'iyah Bireuen sama dengan pemeriksaan saksi-saksi lainnya. Mahkamah Syar'iyah Bireuen akan memeriksa syarat formil dan materil untuk membuat penetapan permohonan diterima atau tidak. Majelis hakim atau ketua hakim menanyakan kepada saksi tentang identitas yang meliputi nama, umur, pekerjaan, tempat tinggal, hubungan saksi dengan para pihak, dan apakah ada hubungan keluarga, perkawinan ataupun hubungan kerja, setelah itu semua di periksa seperti biasa mulai dari sumpah saksi sampai keterangan saksi dikonfirmasi terlebih dahulu kepada para pihak.Penerapan saksi testimonium de audituini juga dalam perkara itsbat nikah di Mahkamah Syar'iyah Bireuen tidak otomatis ditolak sehingga tidak ada nilainya sama sekali, karena dapat diterima sebagai alat bukti dengan menganalisis dasar eksepsional untuk dapat diterimanya dengan mempertimbangkan sejauh mana kualitas dan nilai kekuatan pembuktiannya yang melekat pada keterangan saksi de auditu tersebut, dasar penerimaannya dengan mengambil alih beberapa sumber hukum yang digunakan oleh majelis hakim dalam memeriksa dan membuat putusan baik dalam hukum perdata maupun hukum Islam.Disarankan kepada Mahkamah Syariah Bireuen selain tetap berpegang pada aturan yang berlaku berkaitan dengan saksi juga melihat kepada kasus-kasus yang terjadi dalam masyarakat sehingga keadilan, kepastian dan kemamfatan hukum terjadi.Selain ini Mahkamah Syariah Bireuen juga memperhatikan prosedur seorang boleh dijadikan saksi.

Kata Kunci: Saksi Testimonium de Auditu, Itsbat Nikah

\section{A. Latar Belakang Masalah}

Perkawinan merupakan ikatan lahir batin antara seorang pria dan seorang wanita sebagai suami isteri. ${ }^{1}$ Tujuan perkawinan menurut Undang-Undang Nomor 1 Tahun 1974 tentang Perkawinan (Undang-Undang Perkawinan) adalah untuk membentuk keluarga yang bahagia dan kekal berdasarkan Ketuhanan Yang Maha Esa. ${ }^{2}$ Ikatan perkawinan secara yuridis tersebut menimbulkan akibat hukum, tidak hanya terhadap diri pribadi masing-masing suami isteri yang melangsungkan pernikahan, melainkan lain dari itu bahwa suami dan atau istri mempunyai hak dan kewajiban masing-masing yang mengikat.

Sejak dikeluarkannya Undang-Undang Nomor 7 Tahun 1989 tentang Peradilan Agama (Undang-Undang Peradilan Agama), maka Pengadilan Agama memiliki kedudukan dan eksistensi yang sederajat dengan lembaga peradilan lainnya, seperti peradilan umum, peradilan tata usaha negara, dan peradilan

\footnotetext{
${ }^{1}$ Undang-undang Perkawinan Republik Indonesia Nomor 1 Tahun 1974, Cet. II, (Surabaya:Tinta Mas, 1990), hlm. 7.

${ }^{2}$ Mohd Idris Ramulyo, Hukum Perkawinan Islam: Suatu Analisis UU No. 1 Tahun 1974 dan KHI,(Jakarta: Bumi Aksara, 1996), hlm. 28.
} 
militer. ${ }^{3} \mathrm{Hal}$ ini patut disyukuri, karena selain sebagai ungkapan manifestasi kesadaran historis, juga merupakan bagian yang tidak terpisahkan dari supremasi hukum sesuai dengan lingkup kompetensinya.

Sesuai Pasal 49 ayat (1) Undang-Undang Peradilan Agama menyebutkan bahwa Pengadilan Agama bertugas dan berwenang memeriksa, memutus, dan menyelesaikan perkara di tingkat pertama antara orang-orang yang beragama Islam. Pasal ini kemudian dalam penjelasan umum, angka 2 alinea ketiga dicantumkan bahwa Pengadilan Agama merupakan Pengadilan tingkat pertama untuk memeriksa, memutus, dan menyelesaikan perkara-perkara antara orangorang yang beragama Islam di bidang perkawinan, kewarisan, wasiat, hibah, wakaf, zakat, infaq, shadaqah berdasarkan hukum Islam. ${ }^{4}$ Selain tugas dan wewenang tersebut, dalam Undang-Undang Nomor 3 Tahun 2006 tentang Perubahan Undang-Undang Peradilan Agama, Pengadilan agama diberi tugas dan wewenang lain, yaitu di bidang ekonomi syari'ah.

Berkaitan dengan Peradilan Agama ini pemerintah pusat memberikan kekhususan untuk Provinsi Nanggroe Aceh Darussalam untuk membentuk Mahkamah Syar'iyah sebagai Peradilan Syariat Islam. Hal ini diatur dalam Undang-undang Nomor 18 Tahun 2001 tentang Otonomi Khusus bagi Provinsi Daerah Istimewa Aceh sebagai Provinsi Nanggroe Aceh Darussalam. Masyarakat Aceh menyambut dengan senang hati peluang tersebut yang diharapkan akan lebih mempermudah memperkuat landasan yurudis pelaksanaan Syari'at Islam yang diberikan dengan Undang-undang Nomor 44 Tahun 1999 tentang Penyelenggaraan Keistimewaan Aceh. Menindaklanjutinya maksud UndangUndang tersebut, Pemerintah Daerah Nanggroe Aceh Darussalam mengeluarkan Qanun Nomor 10 Tahun 2002 tentang Peradilan Syari'at Islam yang antara lain mengatur bahwa pembentukan Mahkamah Syar'iyah dilakukan dengan mengembangkan Pengadilan Agama menjadi Mahkamah Syar'iyah dengan memberikan kewenangan yang lebih luas.

Perubahan Pengadilan Agama di Nanggroe Aceh Darussalam menjadi Mahkamah Syar'iyah dan Pengadilan Tinggi Agama menjadi Mahkamah Syar'iyah Provinsi telah dikuatkan dengan Kepres Nomor 11 Tahun 2003 tentang Mahkamah Syar'iyah dan Mahkamah Syar'iyah Provinsi di Provinsi Nanggroe Aceh Darussalam.

Mahkamah Syar'iyah Bireuen sebagai Mahkamah Syar'iyah tingkat pertama yang mempunyai wewenang memeriksa, mengadili, memutus, dan menyelesaikan perkara yang meliputi bidang ahwal al-syakhsyiyah (hukum keluarga), muamalah (hukum perdata), dan jinayah (hukum pidana) yang didasarkan atas syari'at Islam yang yurisdiksinya mencakup Kabupaten BireuenProvinsi Aceh. Kabupaten Bireuen sendiri terdiri dari 17 Kecamatan dan 609 Desa, penduduk Kabupaten

${ }^{3}$ M. Yahya Harahap, Kedudukan Kewenangan dan Acara Peradilan Agama: Undangundang No. 7 Tahun 1989, Cet. II, (Jakarta: Pustaka Kartini, 1993), hlm. 88-89; Jaenal Aripin, Peradilan Agama dalam Bingkai Reformasi Hukum di Indonesia, (Jakarta: Kencana, 2008), hlm. 10.

${ }^{4}$ Lihat Undang-Undang Nomor 7 Tahun 1989 tentang Peradilan Agama.Lihat juga M. Yahya Harahap, Op. Cit, hlm. 135. 
Bireuen mayoritas beragama Islam dan suku mayoritas penduduknya adalah Suku Aceh. $^{5}$

Dalam proses beracara di Mahkamah Syar'iyah Bireuen tidak lepas dari masalah pembuktian, karena dengan pembuktian hakim akan mendapat gambaran yang jelas terhadap perkara yang dipermasalahkan. Pembuktian di muka sidang Pengadilan merupakan hal yang terpenting dalam Hukum Acara, sebab pengadilan dalam menegakkan hukum dan keadilan tidak lain berdasarkan pembuktian. ${ }^{6}$ Selain itu, pembuktian juga merupakan tahap spesifik dan menentukan. ${ }^{7}$ Mahkamah Syar'iyah Bireuen memeriksa terlebih dahulu secara cermat dan teliti dalam menyelesaikan suatu perkarasebelum menjatuhkan putusan yang menggunakan alat bukti saksi tidak melihat secara langsung.Di dalam beberapa kasus istbat nikah sering kali sulit untuk di ungkap karena pada umumnya di dalam melakukan pembuktian di peradilan sangat sulit menemukan saksi-saksi yang melihat langsung kejadian tersebut, dimana bila dilihat dari banyaknya kasus yang terjadi seperti ini pada umunya dilakukan pada masa lampau sehingga akan sangat sulit bila mencari saksi yang melihat kejadian tersebut secara langsung.

Hukum pembuktian dalam hukum acara perdata menduduki tempat yang amat penting dan sangat kompleks dalam proses litigasi. Keadaan kompleksitasnya makin rumit, karena pembuktian berkaitan dengan kemampuan merekonstruksi kejadian atau peristiwa masa lalu (past event) sebagai suatu kebenaran (truth). Meskipun kebenaran yang dicari dan diwujudkan dalam proses peradilan perdata bukan kebenaran yang bersifat absolut, tetapi kebenaran yang bersifat relatif atau bahkan cukup bersifat kemungkinan namun untuk mencari kebenaran yang demikian tetap menghadapi kesulitan. ${ }^{8}$

Hukum acara atau hukum formil bertujuan untuk memelihara dan mempertahankan hukum materil. Secara formal hukum pembuktian mengatur bagaimana mengadakan pembuktian seperti terdapat dalam Het Herziene Indonesisch Reglement (HIR) dan Rechtglement Buitengewesten (R.Bg), sedangkan secara materil, hukum pembuktian mengatur bagaimana diterima atau tidaknya pembuktian dengan alat-alat bukti tertentu di persidangan dan kekuatan pembuktian dari alat-alat bukti yang lain.

Hukum Acara yang berlaku di lingkungan Peradilan Agama/Mahkamah Syar'iyah adalah hukum acara perdata yang berlaku pada pengadilan dalam lingkungan Peradilan Umum, kecuali yang telah diatur khusus dalam UndangUndang. Hal tersebut sebagaimana yang diatur dalam Pasal 54 Undang-Undang Nomor 7 Tahun 1989 jo. Undang-Undang Nomor 3 Tahun 2006 tentang Perubahan Undang-Undang Nomor 7 Tahun 1989 tentang Peradilan Agama. hlm. 13 .

${ }^{5}$ Badan Pusat Statistik Kabupaten Bireuen, Bireuen Dalam Angka, (BPS Bireuen, 2012)

${ }^{6}$ Roihan Rasyid, Hukum Acara Peradilan Agama, (Jakarta: Rajawali, 1991), hlm. 137.

${ }^{7}$ Lilik Mulyadi, Hukum Acara Perdata Menurut Teori dan Praktek Peradilan Indonesia, (Jakarta: Djambatan, 1999), hlm. 150.

${ }^{8}$ M. Yahya Harahap, Hukum Acara Perdata: Gugatan, Persidangan, Penyitaan, Pembuktian dan Putusan Pengadilan, (Jakarta: Sinar Grafika, 2005), hlm. 498. 
Secara umum, beban pembuktian yang dianut oleh hukum acara di Indonesia adalah beban pembuktian berazaskan bahwa "Siapa yang mendalilkan, maka wajib untuk membuktikannya, begitu pula dengan yang membantah hak orang lain wajib untuk membuktikannya." Asas tersebut dapat ditemukan dalam Pasal 1865 KUH Perdata yang berbunyi:"setiap orang yang mendalilkan bahwa ia mempunyai sesuatu hak, atau guna meneguhkan haknya sendiri maupun membantah suatu hak orang lain maka menunjuk pada suatu peristiwa, diwajibkan membuktikan adanya hak atau peristiwa tersebut."10

Sistem pembuktian dalam perkara perdata, sebagaimana dijelaskan oleh M. Yahya Harahap ke dalam fungsi dan peran hakim dalam proses perkara perdata hanya terbatas, yaitu mencari dan menemukan kebenaran formil; dan kebenaran itu diwujudkan sesuai dengan dasar alasan dan fakta-fakta yang diajukan oleh para pihak selama proses persidangan berlangsung. ${ }^{11}$

Alat bukti dalam Hukum Acara Perdata yang disebutkan dalam ketentuan Pasal 164 HIR, Pasal 284 R.Bg dan Pasal 1866 BW ada 5 macam, diantaranya: suarat, saksi, paersangkaan, pengakuan dan sumpah. ${ }^{12}$

Mengenai alat bukti saksi ${ }^{13}$ dalam Hukum Acara Perdata diatur dalam Pasal 139-157 HIR, Pasal 168-172 HIR jo. Pasal 165-179 R.Bg, Pasal 284, 306-309 R.Bg, KUH Perdata Pasal 1866-1880, Pasal 1902-1908 BW dan Pasal 1912 BW. Berdasarkan Pasal 308 RBg, Pasal 171 HIR, Pasal 1970 KUH Perdata, keterangan yang diberikan oleh seorang saksi di persidangan haruslah berdasarkan sumber pengetahuan yang jelas dan sumber pengetahuan yang dibenarkan hukum. Dalam arti kata, kesaksian ${ }^{14}$ tersebut berdasarkan penglihatan, atau pendengaran yang bersifat langsung dari peristiwa atau kejadian yang berhubungan dengan pokok perkara yang disengketakan para pihak.

Apabila saksi yang diajukan atau yang ada tersebut tidak melihat atau mengalami secara langsung, melainkan mendengar dari orang lain (testimonium de auditu). Dalam perkara itsbat nikah (pengesahan nikah), dalam beberapa kasus, peristiwa nikah yang akan disahkan kejadiannya sudah sangat lama sekali sehingga tidak dijumpai lagi orang-orang yang menyaksikan peristiwa nikah tersebut. sebagai contoh, Termohon I telah menikah dengan Termohon II pada tahun 1950 atau di bawah tahun tersebut, oleh karena pernikahan pada masa itu tidak dikeluarkan akta nikah maka Termohon I dan Termohon II tidak memiliki

\footnotetext{
${ }^{9}$ R. Soesilo, RIB/HIR dengan Penjelasan, (Bogor: Politeia, 1995), hlm. 119.

${ }^{10}$ Kitab-Kitab Hukum Perdata (Burgerlijk Wetboek), diterjemahkan oleh Subekti dan R. Tjitrosudibio, (Jakarta: Pradnya Paramita, 2008), Pasal 1865.

${ }^{11}$ M. Yahya Harahap, Op. Cit., hlm. 499.

${ }^{12}$ Hensyah Syahlani, Pembuktian dalam Beracara Perdata \& Teknis Penyusunan Putusan Pengadilan Tingkat Pertama, (tp,: tt, 2007), hlm. 22.

${ }^{13}$ Pengertian saksi adalah orang yang memberikan keterangan di muka sidang pengadilan dengan memenuhi syarat-syarat tertentu, tentang suatu peristiwa atau keadan yang dia lihat, dengar dan ia alami sendiri sebagai bukti kejadiannya peristiwa atau keadaan tersebut.Mukti Arto, $O p$. Cit., hlm. 165 .

${ }^{14}$ Kesaksian adalah kepastian yang diberikan kepada hakim dalam persidangan tentang kejadian-kejadian yang dilihat, didengar dan dialami sendiri mengenai sesuatu yang dipersengketakan dengan jalan menerangkan secara lisan dan pribadi oleh orang, yang bukan salah satu pihak yang sedang berperkara.Sudikno Mertokusumo, Hukum Acara Perdata Indonesia, (Yogyakarta: Liberty, 1988), hlm. 128.
} 
bukti terhadap pernikahan ${ }^{\text {mereka }}$, pada masa sekarang ini untuk suatu kepentingan maka Termohon I dan Termohon II sangat membutuhkan akta nikah sehingga mengajukan perkara itsbat nikah ke Mahkamah Syar'iyah Bireuen. Kemudian ternyata Termohon I dan Termohon II sebagai Para Pemohon dalam meneguhkan dalil-dalil permohonannya hanya dapat menghadirkan saksi testimonium de auditu, karena saksi-saksi yang menyaksikan pernikahan mereka secara langsung sudah meninggal semua. Berdasarkan latar belakang yang telah diuraikan tersebut di atas, maka yang menjadi permasalahan yaitu bagaimana prosedur pembuktian saksi testimonium de auditu dalam perkara itsbat nikah di Mahkamah Syar'iyah Bireuen dan bagaimana penerapan saksi testimonium de auditu dalam perkara itsbat nikah di Mahkamah Syar'iyah Bireuen.

\section{B. Metode Penelitian}

Penelitian ini digolongkan kepada penelitian field research (penelitian lapangan) yaitu menggunakan metode empiris yaitu "Penelitian hukum mengenai pemberlakuan atau implementasi ketentuan hukum normatif secara in action pada setiap peristiwa hukum tertentu yang terjadi dalam masyarakat. ${ }^{15}$ Dalam hal ini penulis meneliti penerapan asas-asas hukum pembuktian dalam hukum acara perdata terkhusus mengenai asas-asas hukum mengenai alat bukti keterangan saksi testimonium de auditu dalam perkara itsbat nikah dan bagaimana penerapannya dalam pertimbangan hakim Mahkamah Syar'iyah Bireuen dalam memeriksa dan mengadili perkara itsbat nikah. Berdasarkan jenis penelitian sebagai mana tersebut di atas maka metode pendekatan yang dipergunakan dalam penelitian ini adalah pendekatan metode empiris (yuridis sosiologis), maka peneliti memulai dari berlakunya hukum positif dan pengaruh berlakunya hukum positif terhadap kehidupan masyarakat terkhusus bagi para Hakim Mahkamah Syar'iyah selaku salah satu aparat penegak hukum yang memeriksa dan mengadili perkara perdata pada pengadilan tingkat pertama serta pengaruh faktor non hukum terhadap terbentuknya serta berlakunya ketentuan hukum positif di tengah-tengah masyarakat. Penelitian ini dilakukan secara metodologis, sistematis dan konsisten. Metodologis yang dimaksud berarti sesuai dengan metode atau cara tertentu, sistematis adalah berdasarkan suatu sistem, dan konsisten berarti tidak adanya halhal yang bertentangan dengan suatu kerangka tertentu". ${ }^{16}$

Penelitian ini bersifat "deskriptif analitis", artinya penelitian ini tidak hanya bertujuan mendeskripsikan ketentuan-ketentuan dan permasalahan-permasalahan hukum mengenai pengaturan saksi testimonium de auditu sebagai alat bukti dalam perkara itsbat nikah, akan tetapi lebih dari itu ditujukan pula untuk menganalisis ketentuan dan permasalahan tersebut guna menemukan solusi yang dapat digunakan dalam penyempurnaan ketentuan yang ada. Selain dari pada itu penelitian juga akan mendeskripsikan bagaimana pertimbangan Hakim Mahkamah Syar'iyah Bireuen terhadap permasalahan saksi testimonium de aditu dalam perkara itsbat nikah, sehingga akan diketahui ketentuan hukum mana yang dipergunakan oleh Hakim Mahkamah Syar'iyah Bireuen ketika dihadapkan

\footnotetext{
${ }^{15}$ Abdulkadir Muhammad, Hukum dan Penelitian Hukum, (Bandung: Citra Aditya Bakti, 2004), hlm. 134.

${ }^{16}$ Soerjono Seokanto, Op. Cit., hlm. 42.
} 
dengan permasalahan konkrit mengenai saksi testimonium de aditu dalam perkara itsbat nikah yang ditanganinya. Spesifikasi ini menunjukkan bahwa penelitian ini membatasi kerangka studi pada suatu pemberian, suatu analisis atau suatu klasifikasi tanpa secara langsung bertujuan untuk menguji hipotesa-hipotesa atau teori-teori. ${ }^{17}$

Jenis data yang digunakan dalam penelitian ini adalah data primer (field research) yaitu data yang berasal dari data lapangan.Data lapangan tersebut diperoleh dari responden yaitu para hakim Mahkamah Syar'yah Bireuen yang memberikan jawaban terhadap pertanyaan yang diajukan oleh peneliti.Responden merupakan orang atau individu yang terkait secara langsung dengan masalah yang diteliti. ${ }^{18}$ Berdasarkan hal tersebut maka data primer dalam penelitian ini diperoleh dari para Hakim Mahkamah Syar'iyah Bireuen sebagai responden.

Selain menggunakan data primer, penelitian ini juga menggunakan data sekunder yang bersumber dari studi kepustakaan (library research).Yang dimaksud data kepustakaan yakni, bahwa dalam suatu penelitian, menggali datanya dari bahan-bahan tertulis (khususnya berupa teori-teori). ${ }^{19}$ Oleh karena itu, data sekunder dalam penelitian ini berfungsi sebagai data utama atau data pokok penelitian. ${ }^{20}$

Data sekunder yang diperoleh dari studi kepustakaan terdiri dari bahan hukum primer, bahan hukum sekunder dan bahan hukum tertier, ${ }^{21}$ sebagai berikut:

a. Bahan Hukum Primer terdiri dari Kitab Undang-Undang Hukum Perdata (KUH Perdata), R.Bg/HIR, Hukum Acara Perdata dan hukum Islam.

b. Bahan Hukum Sekunder yaitu bahan hukum yang memberikan penjelasan dan petunjuk mengenai bahan hukum primer seperti buku-buku referensi,jurnal hukum, hasil-hasil penelitian, karya ilmiah yang relevan dengan penelitian ini.

c. Bahan Hukum Tersier disebut juga bahan hukum penunjang yang mencakup bahan yang memberi petunjuk-petunjuk maupun penjelasan terhadap bahan hukum primer dan sekunder, yaitu berupa kamus, ensiklopedia.

Keseluruhan data sekunder yang diperoleh ditujukan untuk mendapatkan konsep-konsep, teori-teori dan informasi-informasi mengenai permasalahan yang akan dibahas.

Teknik yang dipergunakan dalam pengumpulan data dilakukan melalui 2 (dua) cara, yaitu pengumpulan data dilakukan dengan metode wawancara (depth interview) secara langsung kepada responden yaitu Hakim Mahkamah Syar'iyah Bireuen dengan mengadakan tanya-jawab (wawancara) secara langsung.Wawancara tersebut berupa wawancara terarah dengan mengajukan pertanyaan secara langsung kepada responden.Untuk itu maka dipersiapkan

\footnotetext{
${ }^{17}$ Alvi Syahrin, Pengaturan Hukum dan Kebijakan Pembangunan Perumahan dan Pemukiman Berkelanjutan, (Medan: Pustaka Bangsa Press, 2003), hlm. 17.

${ }^{18}$ Mukti Fajar ND dan Yulianto Achmad, Dualisme Penelitian Hukum Normatif dan Hukum Empiris, (Jakarta: Pustaka Pelajar, 2010), hlm. 34.

${ }^{19}$ Tatang M. Amirin, Menyusun Rencana Penelitian, Cet. III,(Jakarta: Rajawali, 1990), hlm. 135.

${ }^{20}$ Bambang Sunggono, (I), Penelitian Hukum: Suatu Pengantar, (Jakarta: Raja Grafindo Persada,2002), hlm.194-195.

${ }^{21}$ Ibid.
} 
pelaksanaan wawancara serta dibuat pedoman wawancara sehingga hasil wawancara relevan dengan permasalahan yang diteliti. Penelitian Kepustakaan (library research), pengumpulan data dilakukan dengan cara menghimpun data yang berasal dari kepustakaan, berupa buku-buku atau literatur, jurnal ilmiah, majalah-majalah, peraturan perUndang-undangan yang ada hubungannya dengan masalah yang diteliti serta teori-teori dan asas-asas hukum yang terkait dengan pembuktian saksi testimonium de auditu.

Analisis data dilakukan penyusunan data primer dan data sekunder secara sistematis.Selanjutnya data primer dan data sekunder yang telah disusun secara sistematis dianalisis dengan menggunakan metode deduktif dan induktif. Metode deduktif dilakukan dengan membaca, menafsirkan dan membandingkan sedangkan metode induktif dilakukan dengan menterjemahkan berbagai sumber yang berhubungan dengan permasalahan yang dibahas dalam tesis ini sehingga diperoleh kesimpulan sesuai dengan tujuan yang telah dirumuskan. Dengan demikian dapat dikatakan bahwa analisis data akan dilakukan dengan pendekatan kualitatif dengan kalimat yang sistematis untuk memperoleh kesimpulan jawaban yang jelas dan benar.

Analisis data dalam penelitian ini dilakukan secara kualitatif yakni pemilihan teori-teori pembuktian, asas-asas hukum dan peraturan perundangundangan tentang hukum acara perdata. Kemudian dibuat sistematika Pasal-Pasal yang relevan sehingga akan menghasilkan klasifikasi tertentu sesuai dengan permasalahan yang dibahas dalam penelitian ini. Data yang dianalisis secara kualitatif akan dikemukakan dalam bentuk uraian secara sistematis pula dengan menjelaskan hubungan antara berbagai jenis data, selanjutnya semua data dipilih dan dipilah untuk diolah, selanjutnya dianalisis secara deskriptif sehingga disamping akan menggambarkan dan mengungkapkan dasar hukumnya, tetapi juga dapat memberikan solusi terhadap permasalahan yang dimaksud.

\section{Penerapan Saksi Testimonium de Auditu dalam Perkara Itsbat Nikah di Mahkamah Syar'iyah Bireuen \\ 1. Prosedur Pembuktian Saksi Testimonium De Auditu dalam Perkara Itsbat Nikah di Mahkamah Syar'iyah Bireuen}

Mahkamah Syar'iyah Bireuen bertugas memeriksa, memutus dan menyelesaikan perkara-perkara perdata, yaitu bidang perkawinan, kewarisan, wakaf, hibah dan wasiat antara orang-orang yang beragama Islam. Selain kewenangan tersebut Mahkamah Syar'iyah Bireuen juga diberi tugas lain untuk memeriksa, memutus dan menyelesaikan perkara-perkara di bidang muamalah dan jinayah. Hal ini dimaksudkan sebagai pelayanan hukum dan keadilan yang diberikan untuk memenuhi kebutuhan hukum bagi masyarakat sejak lahir dan sampai manusia meninggal dunia.Sebab sebagaimana diketahui bahwa lembaga peradilan tersebut merupakan peradilan khusus yang diberikan pemerintah pusat yang menangani tiga bidang sekaligus.

Pasal 7 Kompilasi Hukum Islam menyebutkan bahwa: (1) perkawinan hanya dapat dibuktikan dengan Akta Nikah yang dibuat oleh Pegawai Pencatat Nikah; (2) dalam hal perkawinan tidak dapat dibuktikan dengan Akat Nikah, dapat diajukan itsbat nikahnya ke Pengadilan Agama; (3) itsbat nikah yang dapat 
diajukan ke Pengadilan Agama terbatas mengenai hal-hal yang berkenaan dengan : (a) Adanya perkawinan dalam rangka penyelesaian perceraian; (b) Hilangnya Akta Nikah; (c) Adanya keraguan tentang sah atau tidaknya salah satu syarat perkawinan; (d) Adanya perkawinan yang terjadi sebelum berlakunya Undangundang Nomor 1 Tahun 1974 dan; (e) Perkawinan yang dilakukan oleh mereka yang tidak mempunyai halangan perkawinan menurut Undang-Undang Perkawinan.

Pengajuan permohonan itsbat nikah ke Mahkamah Syar'iyah Bireuen, menurut Syarwandi adalah melalui beberapa proses. Setelah suatu permohonan isbat nikah diajukan ke Mahkamah Syar'iyah, tahapan selanjutnya Mahkamah Syar'iyah Bireuen akan menentukan hari sidang. Melalui persidangan, Mahkamah Syar'iyah Bireuen akan memeriksa apakah syarat-syarat formil sudah terpenuhi atau belum. Selanjutnya majelis hakim akan memutuskan atau menetapkan, apakah permohonan isbat nikah tersebut diterima atau sebaliknya. Jika seluruh persyaratan formil sudah terpenuhi, maka Mahkamah Syar'iyah Bireuen akan membuat penetapan atau putusan yang bunyinya: permohonan diterima. Sedangkan jika persyaratan formil tidak terpenuhi, maka majelis hakim akan membuat penetapan atau putusan yang menyatakan: permohonan tidak dapat diterima. $^{22}$

Lebih lanjut Syarwandi mengutarakan bahwa untuk permohonan yang diterima akan dilanjutkan pada pemeriksaan materi perkara, sedangkan bagi permohonan yang tidak dapat diterima maka perkara tidak akan dilanjutkan. Untuk perkara permohonan itsbat nikah yang diterima, jika dalam pemeriksaan unsur-unsur materiil semua sudah terpenuhi, maka majelis hakim akan mengeluarkan penetapan atau putusan yang isinya mengabulkan permohonan isbat nikah. Tetapi sebaliknya jika unsur-unsur materiil tidak atau kurang terpenuhi, maka majelis hakim akan mengeluarkan penetapan atau putusan ditolak. Dengan demikian, data-data tentang penetapan atau putusan yang diterima bisa terdiri dari penetapan atau putusan yang dikabulkan atau ditolak. ${ }^{23}$

Salah satu unsur materiil dan formil dalam perkara isbat nikah adalah saksi, dimana para saksi yang dihadirkan harus memenuhi persyaratan formil dan materil sesuai dengan ketentuan Pasal 171-176 RBg dan Pasal 308-309 RBg, agar kesaksiannya dapat dijadikan alat bukti dan dapat dipertimbangkan oleh Majelis Hakim, meskipun saksi tersebut digolongkan sebagai saksi testimonium de aditu.

Salah satu tahapan yang harus dilalui dalam proses litigasi, khususnya di Mahkamah Syar'yah Bireuen adalah upaya pembuktian. Hal ini menjadi kewajiban para pihak yang berperkara dalam pembuktian adalah meyakinkan majelis hakim tentang dalil-dalil yang dikemukakan tentang sesuatu persangkaan atau dalam pengertian yang lain, yaitu kemampuan para pihak memanfaatkan hukum pembuktian untuk mendukung dan membenarkan hubungan hukum dan peristiwa-peristiwa yang di dalilkan dalam hubungan hukum yang diperkarakan. Oleh karena itulah menjadi suatu asas bahwa barang siapa yang mendalilkan sesuatu, maka harus membuktikanya.Membuktikan artinya mempertimbangkan

${ }^{22}$ Syarwandi, Panitera Mahkamah Syar'iyah Bireuen, Wawancara tanggal 20 Februari 2018

${ }^{23}$ Ibid. 
secara logis kebenaran suatu fakta/peritiwa berdasarkan alat-alat bukti yang sah dan menurut hukum pembuktian yang berlaku. ${ }^{24}$

Pandangan yang tidak jauh berbeda dikemukakan oleh Muhammad Nawawi bahwa sebelum majelis hakim memutuskan suatu perkara, terlebih dahulu harus memulai pemeriksaan yang merupakan tahap-tahap dalam pemeriksaan.Karena bila tanpa adanya pemeriksaan, hakim tidak dapat mengambil keputusan dalam perkara yang ditanganinya. Hal yang paling penting dalam pemeriksaan adalah tahap pembuktian, bisa dikatakan penting karena tahap inilah yang nantinya akan menentukan apakah dalil Pemohon akan terbukti sehingga permohonannya dapat dikabulkan oleh Pengadilan. ${ }^{25}$

Kedua pandangan di atas, pada dasarnya selaras dengan aturan yang ada, sebab untuk membuktikan suatu peristiwa yang disengketakan, hukum acara perdata sudah menentukan alat bukti yang bisa diajukan para pihak di persidangan sebagaimana disebutkan dalam Pasal 164 HIR dan 284 Rbg. Dari alat bukti yang diajukan para pihak, hakim dapat menilai peristiwa hukum apa yang terjadi pada para Pemohon. Dari bukti-bukti yang diajukan para Pemohon nantinya, hakim akan mempertimbangkan hukum apa yang akan diterapkan dalam perkara tersebut. Pembuktian dengan alat bukti saksi sangatlah penting, karena disinilah hakim akan mengetahui jalannya sengketa dengan mendengar dari saksi yang di hadirkan di depan persidangan. Orang yang menjadi saksi biasanya di bawa sendiri oleh para pihak setelah bukti surat selesai diajukan.

Saksi yang mendengar dari pihak lain disebut testimonium de audtiu, saksi ini tidak mendengar ataupun mengalaminya sendiri, akan tetapi mendengar keterangannya dari orang lain. Saksi ini tidak mempunyai nilai pembuktian, tetapi secara kasuistikdapat digunakan sebagai sumber persangkaan atau untuk melengkapi keterangan saksi-saksi yang bisa dipercayai. Pemeriksaan saksi de auditusama halnya dengan saksi-saksi yang lainya, tidak ada bedanya karena semua harus sama dengan peraturan dan prosedur dalam pemeriksaan pembuktian.

Tata cara pemeriksaan saksi de auditu di persidangan Mahkaman Syar'iyah, pada dasarnya pemeriksaan saksi de auditu sama dengan pemeriksaan saksi biasa. Hal ini sebagaimana diutarakan oleh Muhammad Nawawi, yaitu:

1. Saksi dipanggil masuk ke ruang sidang satu-satu dan persidangan dinyatakan terbuka untuk umum kecuali dalam perkara khusus, seperti permasalahan keluarga, perceraian.

2. Majelis hakim/ hakim ketua menanyakan kepada saksi tentang identitas yang meliputi nama, tempat tanggal lahir, umur, agama, pendidikan, pekerjaan, tempat tinggal, hubungan saksi dengan para pihak, dan apakah ada hubungan keluarga, perkawinan ataupun hubungan kerja.

3. Hakim menyuruh saksi berdiri untuk melakukan sumpah menurut tata cara agamanya.

4. Atas pertanyaan hakim saksi memberikan keteranganya sesuai apa yang ia lihat, dengar dan dialami sendiri ataupun yang diketahui. Sedangkan

${ }^{24}$ Rubaiyah, Hakim Mahkamah Syar'iyah Bireuen, Wawancara tanggal 20 Februari 2018.

${ }^{25}$ Muhammad Nawawi, Hakim Mahkamah Syar'iyah Bireuen. Wawancara tanggal 20 Februari 2018. 
saksi de auditu memberikan keteranganya apa yang dia tidak lihat, dengar dan dialami sendiri melainkan besumber dari orang lain. Saksi keluarga (sedarah atau semenda), buruh/kariawan dan pembantu rumah tangga para pihak dapat didengar, dilihat sebagai saksi dibawah sumpah/janji khusus dalam perkara itsbat nikah.

5. Para pihak juga dapat mengajukan pertanyaan kepada saksi terhadap hal yang dianggap penting melalui ketua majelis.

6. Saksi yang telah diperiksa di persilahkan untuk keluar terlebih dahulu untuk bergantian dengan saksi satunya dan agar tidak berhubungan satu sama lain saat proses pemeriksaan saksi sedang berjalan. ${ }^{26}$

Dari uraian di atas sama dengan pernyataan Haris Luthfi, mereka mengemukakan bahwa pemeriksaan saksi dalam kasus perkara perdata lebih khusus perkara itsbat nikah yang saksinya de auditu sama dengan pemeriksaan saksi-saksi lainya tidak ada bedanya. ${ }^{27} \mathrm{Hal}$ senada juga dikemukakan Zulfikri bahwa prosedur pemeriksaan saksi de auditu tidak ada bedanya dengan pemeriksaan saksi lainya. ${ }^{28}$

Dalam prakteknya, prosedur pemeriksaan saksi de auditu tidak melanggar aturan yang ada.Sebab menurut Zulfikri, prosedur pemeriksaan kesaksian tidak langsung (testimonium de auditu) di Mahkamah Syar'iyah Bireuen tidak menyalahi aturan dan tetap pada aturan, karena menggunakan dasar hukum yang cukup kuat untuk dijadikan patokan.Jadi sesungguhnya testimonium de auditu itu dibolehkan dan bisa digunakan menjadi bukti, selagi tidak ada bukti yang melawannya.Seperti yang dikatakan Sayyid Sabiq bahwa kesaksian istifadhah membenarkan. ${ }^{29}$

Kesaksian dalam masalah-masalah termasuk nikah.Zulfikri juga mengatakan bahwa hakim selalu mengacu pada peraturan-peraturan yang ada sebagaimana sudah diatur dalam Undang-undang dan kitab-kitab yang ada, sehingga prosedur pemeriksaannya tetap dalam koridor aturan.Kitab-kitab fiqih yang dijadikan untuk penemuan hukum dalam berperkara adalah sebagai rujukan penting. Penggunaan saksi istifadhah antara lain unsurnya kemasyhuran, beritanya tersebar luas. Penggunaan kesaksian tersebut dalam fiqih adalah merupakan rukhshoh, dalam pembuktian, artinya larangan penggunaan saksi de auditu yang secara umum dikecualikan dengan illat tidak adanya saksi utama, di mana perkara tersebut perlu adanya kepastian hukum. ${ }^{30}$

Seiring proses pemeriksaan perkara di Mahkamah Syar'iyah Bireuen, menurut Rubaiyah sangat jarang menggunakan kesaksian dengan de auditu, penggunaannya hanya ada pada masalah-masalah tertentu saja seperti perkara wakaf dan itsbat nikah. Karena dalam kasus-kasus tertentu pada itsbat nikah, saksi tidak mengetahui secara persis peristiwa nikah, kemungkinankemungkinanya karena pada saat peristiwa nikah terjadi saksi masih muda belia,

\footnotetext{
${ }^{26}$ Ibid.

${ }^{27}$ Haris Luthfi, Hakim Mahkamah Syar'iyah Bireuen, Wawancara tanggal 21 Februari 2018.

${ }^{28}$ Zulfikri, Hakim Mahkamah Syar'iyah Bireuen, Wawancara tanggal 21 Februari 2018.

${ }^{29} \mathrm{Ibid}$; Lihat juga Sayyid Sabiq, Fiqih Sunnah, Jilid 3, (Bairut: Dar al-Fikr, 1983), hlm. 332.

${ }^{30}$ Zulfikri, Op.Cit.
} 
atau pada saat pernikahan dilangsungkan saksi belum lahir sehingga saksi mengetahui peristiwa nikah tersebut dari orang lain. ${ }^{31}$

Penggunaan kesaksian dengan de auditu, menurut Muhammad Nawawi pada prinsipnya harus melalui prosedur pembuktian secara umum menurut ketentuan hukum yang ada, dalam pengertian bahwa saksi tersebut harus memenuhi syarat formil sebagai saksi dan harus memenuhi batas minimal dua orang saksi. Pada beberapa perkara itsbat nikah yang pernah diperiksa ada beberapa kemungkinan terjadinya testimonium de auditu, kemungkinan pertama bahwa hanya satu orang saksi yang mengetahui langsung peristiwa nikah, sedangkan saksi yang lain tidak mengetahui secara langsung pernikahan tersebut, kemungkinan kedua semua saksi mengetahui peritiwa nikah dari orang lain, atau setidaknya para saksi mengetahui dari orang lain bahwa para Pemohon telah menikah. ${ }^{32}$

Meskipun kesaksian dengan de auditu jarang digunakan dalam proses pemeriksaan perkara di Mahkamah Syar'iyah Bireuen, kecuali dalam kasus-kasus tertentu salah satunya itsbat nikah. Akan tetapi para hakim mempunyai acuan atau landasan berpijak sebagaimana diatur dalam peraturan perungdang-undangan, sehingga dalam proses pemeriksaan tidak keluar ketentuan yang ada.Pemeriksaan saksi testimonium de auditu sama saja dengan pemeriksaan saksi-saksi lainya tidak ada bedanya. Majelis hakim atau hakim ketua menanyakan kepada saksi tentang identitas yang meliputi nama, umur, agama, pendidikan, pekerjaan, tempat tinggal, hubungan saksi dengan para pihak, dan apakah ada hubungan keluarga, perkawinan ataupun hubungan kerja, setelah itu semua diperiksa seperti biasa diawali dengan penyumpahan kepada saksi.

Penggunaan saksi testimonium de aditu atau saksi istifadhah dalam perkara isbat nikah menurut Para Hakim Mahkamah Syar'iyah Bireuen sifatnya kasuistis jadi tidak semua perkara isbat nikah dibenarkan untuk menerima keterangan saksi de aditu tersebut, kasus sebagaimana dimaksud yaitu terkhusus terhadap perkaraperkara isbat nikah yang sudah lama atau lampau kejadian peristiwa nikahnya, di mana tidak ada lagi saksi utama yang mengetahui secara persis kejadian nikah tersebut. Selain dari pada itu menurut para Hakim Mahkamah Syar'iyah Bireuen, keterangan saksi testimonium de aditu tidak begitu saja mutlak dapat diterima keterangannya, untuk menambah keyakinannya maka Hakim dapat memerintahkan Para pihak agar mengangkat sumpah pelengkap (supletoir) yang menyatakan bahwa pernikahan tersebut telah memenuhi syarat dan rukun perkawinan menurut ketentuan hukum, dengan demikian maka perinsip kehatihatian agar tidak terjadinya penyeludupan hukum dalam perkara itsbat nikah dapat diminimalisir.

Menurut Amiruddin, prosedur pemeriksaan saksi de auditu tidak menyalahi aturan atau regulasi yang sudah ada, prosedur pemeriksaan kesaksian testimonium de auditu di Mahkamah Syar'iyah Bireuen berlandaskan dasar hukum yang cukup kuat untuk dijadikan patokan, karena sesungguhnya testimonium de auditu itu dibolehkan dan bisa digunakan menjadi bukti selama tidak ada bukti yang

\footnotetext{
${ }^{31}$ Rubaiyah, Op.Cit.

${ }^{32}$ Muhammad Nawawi, Op. Cit.
} 
melawanya. Hal ini sebagaimana dikatakan oleh sayyid sabiq dalam kitabnya fiqih sunnah jilid 3 halaman 332 bahwa kesaksian iftifadhoh dibenarkan kesaksiannya. ${ }^{33}$

Prosedur pembuktian saksi testimonium de auditu dalam perkara itsbat nikah di Mahkamah Syar'iyah Bireuen, sebagaimana yang telah diuraikan apabila dikaitkan dengan teori pembuktian di atas, maka Para Hakim Mahkamah Syar'iyah Bireuen menerapkan teori pembuktian bebas, bebas dalam pengertian di sini bahwa Hakim bukan mutlak menerima testimonium de auditu tanpa terikat dengan aturan mengenai pembuktian saksi, akan tetapi Hakim tetap mengacu kepada syarat-syarat formil mengenai saksi sebagaimana yang ditentukan undangundang, hanya saja mengenai syarat materiil saksi testimonium de auditu tersebut Hakim menilainya sebagai bukti awal yang dijadikan persangkaan yang kemudian dikonstruksikan menjadi sebuah fakta, untuk menjadikan fakta tersebut menjadi fakta hukum maka Hakim Mahkamah Syar'iyah Bireuen dalam rangka menambah keyakinannya dapat melengkapi bukti tersebut dengan sumpah supletoir (pelengkap) dari Para Pihak, dengan demikian maka kelemahan dalam teori pembuktian bebas tersebut yaitu adanya kesewenang-wenangan Hakim dalam menilai alat bukti tidak terjadi. Selain dari pada itu dengan menerapkan prosedur tersebut maka perinsip kehati-hatian juga telah terpenuhi dalam memutus perkara itsbat nikah, karena tak jarang terjadi adanya penyeludupan hukum dalam pengajuan perkara isbat nikah.

\section{Penerapan Saksi Testimonium De Auditu dalam Perkara Itsbat Nikah di Mahkamah Syar'iyah Bireuen}

Terhadap perkara itsbat nikah yang diputus di Mahkamah Syar'iyahBireuendalam proses pengambilan putusan ada beberapa pertimbangan. Musyawarah juga dilakukan oleh majelis hakim ketika proses pengambilan putusan terhadap suatu perkara yang mereka tangani. Dalam perkara itsbat nikah,Rubaiyah menyampaikan bahwa testimonium de auditu dibolehkan sepanjang tidak ada bukti yang melawan, sepanjang tidak ada bukti sebaliknya.Sebab testimonium de auditu tidak bersumber dari aslinya, jika ada yang membuktikan sebaliknya maka testimonium de auditu tidak berlaku lagi, bahkan bisa menjadi bukti yang berdiri sendiri bukan bukti tambahan. Dalam hal ini hakim menggambil dasar hukum dari kitab; fiqih sunnah, ushul fiqih, I'anatut thalibin. ${ }^{34}$

Lebih lanjut Rubaiyah mengemukakan bahwa testimonium de auditu itu dibolehkan bilamana berkaitan dengan masalah nikah, hibah, wakaf dan pembebasan budak. Jadi syaratnya yang pertama tidak adanya bukti sebaliknya, yang kedua terkait pernikahan dan yang terakir testimonium de auditu sudah tersiar tidak hanya satu orang saja yang mengetahuinya, tetapi banyak orang kemudian kesaksian yang di dengar dari saudara, kakek, orang tua mereka semua diyakini tidak berbuat dusta. ${ }^{35}$

${ }^{33}$ Drs. Amiruddin, MH, Ketua Mahkamah Syar'iyah Bireuen, Wawancara tanggal 21 Februari 2018 di Ruangan Ketua Mahkamah Syar'iyah Bireuen.

${ }^{34}$ Rubaiyah, Op. Cit.

${ }^{35}$ Ibid. 
Apabila kembali kepada kitab-kitab klasik, memang para imam madzhab memperbolehkan kesaksian de auditu.Ulama Syafi'iyah membenarkan kesaksian istifadhah dalam masalah nasab, kelahiran, kematian, merdekanya seorang budak, kewalian, diangkatnya seseorang menjadi hakim, wakaf, pengunduran diri seseorang darinya, keadilan seseorang, cacat pribadi seseorang, wasiat, kecerdasaan seseorang, kebodohan seseorang dan milik seseorang. Sementara Imam Abu Hanifah berpendapat bahwa diperbolehkan pada lima hal, yaitu nikah, persetubuhan, nasab, kematian dan diangkatnya seseorang menjadi hakim. Sedangkan Imam Ahmad dan sebagian Syafi'iyah berpendapat bahwa ada tujuh hal yang diperbolehkan kesaksian istifadhah didalamnya, yaitu nikah, nasab, kematian, merdekanya seorang budak, kewalian, wakaf, dan miliknya seseorang. ${ }^{36}$

Testimonium de auditu memang sering kali tidak dianggap sebagai bukti tetapi dalam peraturan dan penemuan hukum di Mahkamah Syar'iyah, testimonium bisa dijadikan dan dapat diterima sebagai saksi, seperti yang dikatakan Zulfikri bahwa kesaksian de auditu dapat diterima dan tidak ditolak, karena dalam fiqih sunnah karya Sayyid Sabiq membenarkan kesaksian de auditu boleh dalam masalah yang salah satunya tentang nikah dan itsbat nikah termasuk kedalam kategorinya. Testimonium de auditu juga bisa berdiri sendiri asalkan pada orang banyak dan tidak ada bukti yang melawan, ini tidak akan berbenturan dengan Pasal 171 HIR dan 1907 KUHPerdata, karena dasar kami kuat dengan penemuan hukum dan pertimbangan-pertimbangan manfaat dan kerugianya, jika menerimanya sebagai alat bukti. ${ }^{37}$

Berikut beberapa penetapan atau putusan hakim terhadap perkara itsbat nikah di Mahkamah Syar'iyah Bireun yang menjadikan saksi testimonium de aditu sebagai pertimbangan hukum, yaitu:

1. Perkara Nomor 0042/Pdt.P/2016/MS Bir. Di Mahkamah Syar'iyah Bireuen. Tujuan permohonan isbat nikah untuk memperoleh buku Buku Nikah karena sebelumnya pernikahan tersebut tidak tercatat pada kantor urusan agama Kecamatan Jangka, Kabupaten Bireuen guna untuk menunaikan ibadah haji lansia dan juga untuk dicatat sebagai bukti otentik pada kantor urusan agama Kecamatan Jangka Kabupaten Bireuen. Berdasarkan Pasal 49 Undang-Undang Nomor 7 Tahun 1989 sebagaimana telah diubah dengan Undang-Undang Nomor 3 Tahun 2006 dan perubahan kedua dengan Undang-Undang Nomor 50 Tahun 2009 merupakan kewenangan absolut Pengadilan Agama atau Mahkamah Syar'iyah, sesuai dengan kompetensi relatif dibuktikan dengan fotocopy KTP pemohon I dan Pemohon II serta dua orang saksi yang dihadirkan sesuai dengan ketentuan Pasal 171 - 176 RBg dan Pasal $308-309$ RBg. Meskipun keterangan kedua orang saksi tentang keabsahan pernikahan Pemohon I dan Pemohon II hanya bersumber dari keterangan Pemohon kepada saksi serta masyarakat umum di Desa, bukan atas penglihatan ataupun pendengaran sendiri/langsung (de aditu) akan tetapi para saksi mengetahui sendiri bahwa biasanya pernikahan yang telah dilaksanakan

\footnotetext{
${ }^{36}$ Sayyid Sabiq, Op. Cit, hlm. 332.

${ }^{37}$ Zulfikri, Op. Cit.
} 
berdasarkan hukum Islam yaitu telah terpenuhinya rukun dan syarat pernikahan itu sendiri. Oleh karena saksi yang melihat dan mendengar secara langsung peristiwa sudah tidak ada lagi (sudah meninggal dunia) maka dalam hal ini keterangan saksi de aditu/al-istifadhah sangat diperlukan untuk mengungkapkan dan mendapatkan kebenaran. Berdasarkan bukti-bukti dan keterangan saksi, maka majelis hakim menemukan fatwa perkawinan pemohon sudah memenuhi rukun dan syarat perkawinan sesuai dengan ketentuan Pasal 2 ayat (1) jo. Pasal 64 Undang-Undang Nomor 1 Tahun 1974dan Pasal 7 ayat (3) huruf (d) Kompilasi Hukum Islam, sehingga permohonan tersebut dikabulkan

2. Perkara Nomor 0265/Pdt.G/2016/MS.Bir bertempat di Mahkamah Syar'iyah Bireun. Tujuan permohonan isbat nikah untuk memperoleh buku Nikah guna pengurusan Tunjangan Pensiunan Janda Veteran berhubung pernikahan tersebut terjadi sebelum lahirnya UU Nomor I Tahun 1974 dan bukti otentik berupa Surat Nikah belum ada pada saat itu. Berdasarkan Pasal 49 huruf (a) Undang-Undang Nomor 7 Tahun 1989 dan, maka Mahkamah Syar'iyah Bireuen berwenang memeriksa, mengadili dan memutus perkara $a$ quo;, sesuai dengan kompetensi relatif dibuktikan dengan fotocopy KTP pemohon I dan Pemohon II, fotocopy Petikan Keputusan Direktur Jenderal Potensi Pertahanan Kementerian Pertahanan RI, Nomor KEP/67/08/38/A-IM/VIII/2015, tanggal 04 Agustus 2015 yang dikeluarkan oleh Direktorat Jenderal Potensi Pertahanan Kementerian Pertahanan RI dan Asli Surat Keterangan Meninggal Dunia, Nomor 474/275/2016 serta dua orang saksi yang dihadirkan sudah dewasa dan sudah disumpah, sehingga memenuhi syarat formil sebagaimana diatur dalam Pasal 172 dan 175 R.Bg dan kedua orang saksi tersebut telah memenuhi syarat materiil sebagaimana diatur dalam Pasal 309 R.Bg. Saksi yang dihadirkan Para Pemohon tidak mengetahui peristiwa nikah Para Pemohon, akan tetapi menurut para saksi sampai saat ini tidak ada bantahan atau gugatan dari masyarakat mengenai pernikahan Para Pemohon dari masyarakat, atas dasar hal tersebut maka berprasangka bahwa pernikahan Para Pemohon telah memenuhi syarat dan rukun perkawinan sebagaimana yang ditentukan oleh hukum, sehingga permohonan Para Pemohon dikabulkan.

3. Perkara Nomor 286/Pdt.G/2018/MS.Bir bertempat di Mahkamah Syar'iyah Bireun. Tujuan permohonan isbat nikah untuk memperoleh buku Buku Nikah baru berhubung Buku Nikah Asli sudah tidak dapat dibaca lagi karena sudah dimakan rayap dan akan digunakan sebagai syarat mengurus pensiun almarhum suaminya. Berdasarkan Pasal 49 Undang-Undang Nomor 7 Tahun 1989 sebagaimana telah diubah dengan Undang-Undang Nomor 3 Tahun 2006 dan perubahan kedua dengan Undang-Undang Nomor 50 Tahun 2009 merupakan kewenangan absolut Pengadilan Agama atau Mahkamah Syar'iyah, sesuai dengan kompetensi relatif dibuktikan dengan fotocopy Surat Keterangan Kematian, fotocopy Akta Nikah, fotocopy KTP dan fotocopy Petikan Surat Keputusan Nomor: Skep.12/03/36/A-IM/VI/2003 oleh Direktur Jenderal Kekuatan 
Pertahanan RI serta para saksi yang dihadirkan sesuai dengan ketentuan Pasal 171 - 176 RBg dan Pasal 308 - 309 RBg. Meskipun keterangan kedua orang saksi tentang keabsahan pernikahan Pemohon I dan Pemohon II hanya bersumber dari keterangan Pemohon kepada saksi serta masyarakat umum di Desa, bukan atas penglihatan ataupun pendengaran sendiri/langsung (de aditu) akan tetapi para saksi mengetahui sendiri bahwa biasanya pernikahan yang telah dilaksanakan berdasarkan hukum Islam yaitu telah terpenuhinya rukun dan syarat pernikahan itu sendiri. Oleh karena saksi yang melihat dan mendengar secara langsung peristiwa sudah tidak ada lagi (sudah meninggal dunia) maka dalam hal ini keterangan saksi de aditu/al-istifadhah sangat diperlukan untuk mengungkapkan dan mendapatkan kebenaran. Berdasarkan bukti-bukti dan keterangan saksi, maka majelis hakim menemukan fatwa perkawinan pemohon sudah memenuhi rukun dan syarat perkawinan sesuai dengan ketentuan Pasal 2 ayat (1) jo. Pasal 64 Undang-Undang Nomor 1 Tahun 1974dan Pasal 7 ayat (3) huruf (d) Kompilasi Hukum Islam, sehingga permohonan tersebut dikabulkan

4. Perkara Nomor 0304/Pdt.G/2018/MS.Bir.bertempat di Mahkamah Syar'iyah Bireun. Tujuan permohonan isbat nikah untuk memperoleh buku Buku Nikah baru berhubung Buku Nikah Asli sudah tidak dapat dibaca lagi karena sudah dimakan rayap dan akan digunakan sebagai syarat mengurus pensiun almarhum suaminya. Berdasarkan Pasal 49 Undang-Undang Nomor 7 Tahun 1989 sebagaimana telah diubah dengan Undang-Undang Nomor 3 Tahun 2006 dan perubahan kedua dengan Undang-Undang Nomor 50 Tahun 2009 merupakan kewenangan absolut Pengadilan Agama atau Mahkamah Syar'iyah, sesuai dengan kompetensi relatif dibuktikan dengan fotocopysurat Keterangan Nomor 470/6.100/2018yang dikeluarkan oleh Pemerintah Kabupaten Bireuen, Provinsi Aceh, Fotokopi Petikan Surat Keputusan Direktur Jenderal Potensi Pertahanan Tentang Pemberian Dana Kehormatan Veteran, Tunjangan Veteran Dan Tunjangan Janda/Duda/Yatim Piatu Veteran Pejaung/Pembela Kemerdekaan Republik Indonesia Nomor: KEP/72/AIM/III/2018 serta para saksi yang dihadirkan sesuai dengan ketentuan Pasal 171 - 176 RBg dan Pasal 308 - 309 RBg. Majelis mempertimbangkan meskipun keterangan kedua orang saksi tentang keabsahan pernikahan Pemohon I dan Pemohon II hanya bersumber dari keterangan Para Pemohon kepada saksi serta masyarakat umum di Desa, bukan atas penglihatan ataupun pendengaran sendiri/langsung (de aditu) akan tetapi para saksi mengetahui sendiri bahwa biasanya pernikahan yang telah dilaksanakan berdasarkan hukum Islam yaitu telah terpenuhinya rukun dan syarat pernikahan itu sendiri. Oleh karena saksi yang melihat dan mendengar secara langsung peristiwa sudah tidak ada lagi (sudah meninggal dunia) maka dalam hal ini keterangan saksi de aditu/al-istifadhah sangat diperlukan untuk mengungkapkan dan mendapatkan kebenaran. Berdasarkan bukti-bukti yang diajukan Para Pemohon maka Majelis Hakim menemukan fakta bahwa perkawinan 
Para Pemohon sudah memenuhi rukun dan syarat perkawinan sesuai dengan ketentuan pasal 2 ayat (1) jo. Pasal 64 Undang-Undang Nomor 1 Tahun 1974dan Pasal 7 ayat (3) huruf (d) Kompilasi Hukum Islam, sehingga permohonan tersebut dikabulkan.

Berdasarkan keempat putusan hakim tersebut di atas dapat dianalisis bahwa penerapan saksi testimonium de auditu di Mahkamah Syar'iyah Bireuen dapat dijadikan sebagai alat bukti bagi hakim dalam menetapkan sebuah putusan berdasarkan berbagai pertimbangan.

Pertama, putusan Nomor: 0042/Pdt.P/2016/MS Bir, Majelis Hakim memutuskan perkara itsbat nikah dengan pertimbangan alat bukti dua orang saksi yang diajukan Para Pemohon di persidangan, Majelis Hakim berpendapat bahwa saksi-saksi Para Pemohon telah memenuhi persyaratan formil dan persyaratan materil, sesuai dengan ketentuan Pasal 171 - 176 RBg dan Pasal 308 - 309 RBg. Berdasarkan keterangan saksi I dan saksi II tidak melihat langsung Pemohon I dan Pemohon II menikah karena saksi I masih di bawah umur (masih anak-anak) dan saksi II belum lahir.Majelis Hakim menilai keterangan kedua orang saksi tersebut digolongkan sebagai testimonium de aditu, meskipun pernikahan telah dilaksanakan berdasarkan hukum Islam, yaitu telah terpenuhinya rukun dan syarat. Keterangan saksi de aditu atau al-istifadhah sangat diperlukan untuk mengungkapkan dan mendapatkan kebenaran atau informasi yang benar dalam perkara ini, karena saksi yang melihat dan mendengar secara langsung peristiwa nikah sudah tidak ada lagi (sudah meninggal dunia).

Kedudukan saksi yang pengetahuannya berdasarkan pada berita yang sudah menyebar luas (syahadah al-istfadhah) dalam masalah pernikahan adalah dibenarkan untuk diterima. Sebagaimana yang disebutkan dalam kitab fiqih sunnah karya Sayyid Sabiq jilid III halaman 426. Majelis Hakim memandang perlu mengetengahkan pendapat ahli Fikih dalam Kitab I'anatut Thalibin juz IV halaman 254 yaitu "Dan didalam pengakuan tentang pernikahan dengan seorang wanita, harus dapat menyebutkan tentang sahnya pernikahan dahulu dan syaratsyaratnya seperti wali dan dua orang saksi yang adil".

Ketentuan Pasal 7 ayat (3) Kompilasi Hukum Islam disebutkan "mengenai hal-hal yang berkenaan dengan: a. adanya perkawinan dalam rangka penyelesaianperceraian; $b$. hilangnya akta nikah; $c$. adanya keraguan tentang sah atau tidaknyasalah satu syarat perkawinan; d. adanya perkawinan yang terjadi sebelum berlakunya Undang-undang No. 1 Tahun 1974, dan; e. perkawinan yang dilakukan oleh mereka yang tidak mempunyai halangan perkawinan menurut halangan perkawinan Undang-undang No. 1 Tahun 1974”. Ketentuan hukum dan doktrin Hukum Islam (pendapat ahli fikih), maka permohonan itsbat nikah yang diajukan telah sesuai dengan Pasal 2 ayat (2) Undang-Undang Nomor 1 Tahun 1974 tentang perkawinan dan Pasal 7 ayat (3) huruf (d) Kompilasi Hukum Islam, maka permohonan Pemohon patut untuk dikabulkan

Dalam bidang perkawinan, sesuai ketentuan pasal 89 ayat 1 UndangUndang Nomor 7 Tahun 1989 sebagaimana perubahan pertama dengan Undangundang Nomor 3 Tahun 2006 dan perubahan kedua dengan Undang-undang 
Nomor 50 Tahun 2009, maka segala biaya yang timbul dalam perkara ini dibebankan kepada Pemohon, yang dinyatakan dalam amar putusan ini.

Kedua, putusan Nomor:0265/Pdt.G/2016/MS.Bir. Majelis hakim memutuskan perkara isbat nikah dengan pertimbangansaksi 1 Pemohon adalah ibu kandung Termohon, sementara saksi 2 Pemohon, sudah dewasa dan sudah disumpah, sehingga memenuhi syarat formil sebagaimana diatur dalam Pasal 172, 175 dan 308 R.Bg.

Ketiga, putusanNomor: 286/Pdt.G/2018/MS.Bir.Majelis hakim memutuskan perkara isbat nikah dengan pertimbangan:

Alat bukti dua orang saksi yang diajukan Pemohon di persidangan, telah memenuhi persyaratan formil dan persyaratan materil, sesuai dengan ketentuan Pasal 171 - 176 RBg dan Pasal 308 dan 309 RBg. Dan keterangan kedua orang saksi tersebut mengenai peristiwa hukum pernikahan digolongkan sebagai testimonium de aditu/al-istifadhah sangat diperlukan untuk mengungkapkan dan mendapatkan kebenaran/informasi yang benar dalam perkara ini.

Dalam hukum Islam kedudukan saksi yang pengetahuannya berdasarkan pada berita yang sudah menyebar luas (syahadah al-istfadhah) dalam masalah pernikahan adalah dibenarkan untuk diterima, sebagaimana disebutkan dalam kitab fiqih sunnah karya Sayyid Sabiq, jilid III halaman 426.

Majelis Hakim memandang perlu mengetengahkan pendapat ahli Fikih dalam Kitab I'anatut Thalibin juz IV halaman 254 yaitu "Dan didalam pengakuan tentang pernikahan dengan seorang wanita, harus dapat menyebutkan tentang sahnya pernikahan dahulu dan syarat-syaratnya seperti wali dan dua orang saksi yang adil".

Ketentuan Pasal 7 ayat (3) Kompilasi Hukum Islam disebutkan "mengenai hal-hal yang berkenaan dengan: a. adanya perkawinan dalam rangka penyelesaianperceraian; b. hilangnya akta nikah; $c$. adanya keraguan tentang sah atau tidaknyasalah satu syarat perkawinan; d. adanya perkawinan yang terjadi sebelum berlakunya Undang-undang No. 1 Tahun 1974, dan; e. perkawinan yang dilakukan oleh mereka yang tidak mempunyai halangan perkawinan menurut halangan perkawinan Undang-undang No. 1 Tahun 1974”.

Ketentuan hukum dan doktrin hukum Islam, permohonan itsbat nikah yang diajukan sesuai dengan Pasal 2 ayat (2) Undang-Undang Nomor 1 Tahun 1974 tentang perkawinan dan Pasal 7 ayat (3) huruf (d) Kompilasi Hukum Islam, maka permohonan Pemohon patut untuk dikabulkan.

Ketentuan Pasal 2 ayat (2) Undang-Undang Nomor 1 Tahun 1974 tentang Perkawinan jo. Pasal 2 ayat (1) Peraturan Pemerintah Nomor 9 Tahun 1975 tentang Pelaksanaan Undang-undang Nomor 1 Tahun 1974 Tentang perkawinan jo. Pasal 5 Ayat (1) Kompilasi Hukum Iskam, Majelis Hakim memandang perlu memerintahkan kepada Pemohon untuk mencatatkan perkawinannya kepada Pegawai Pencatat Nikah pada Kantor Urusan Agama yang mewilayahi tempat tinggalnya.

Keempat,putusanNomor: $\quad$ 0304/Pdt.G/2018/MS.Bir.Majelis hakim memutuskan perkara isbat nikah dengan pertimbangan: 
Ketentuan Pasal 7 ayat (4) Kompilasi Hukum Islam, yang berhak mengajukan permohonan itsbat nikah ialah suami atau istri,anak-anak mereka, wali nikah dan pihak yang berkepentingan dengan perkawinan itu.

Alat bukti dua orang saksi yang diajukan Pemohon di persidangan, telah memenuhi persyaratan formil dan materil, sesuai dengan ketentuan Pasal 171 sampai 176 RBg dan Pasal 308 dan 309 RBg digolongkan sebagai testimonium de aditu/al-istifadhah sangat diperlukan untuk mengungkapkan dan mendapatkan kebenaran/informasi yang benar dalam perkara ini.

Hukum Islam menyatakan kedudukan saksi yang pengetahuannya berdasarkan pada berita yang sudah menyebar luas (syahadah al-istfadhah) dalam masalah pernikahan adalah dibenarkan untuk diterima, sebagaimana disebutkan dalam kitab fiqih sunnah karya Sayyid Sabiq, jilid III halaman 426.

Majelis Hakim memandang perlu mengetengahkan pendapat ahli Fikih dalam Kitab I'anatut Thalibin juz IV halaman 254 yaitu "Dan didalam pengakuan tentang pernikahan dengan seorang wanita, harus dapat menyebutkan tentang sahnya pernikahan dahulu dan syarat-syaratnya seperti wali dan dua orang saksi yang adil”.

Ketentuan Pasal 7 ayat (3) Kompilasi Hukum Islam disebutkan "mengenai hal-hal yang berkenaan dengan: a. adanya perkawinan dalam rangka penyelesaianperceraian; $b$. hilangnya akta nikah; $c$. adanya keraguan tentang sah atau tidaknyasalah satu syarat perkawinan; $d$. adanya perkawinan yang terjadi sebelum berlakunya Undang-undang No. 1 Tahun 1974, dan; e. perkawinan yang dilakukan oleh mereka yang tidak mempunyai halangan perkawinan menurut halangan perkawinan Undang-undang No. 1 Tahun 1974”.

Berdasarkan ketentuan hukum dan doktrin Hukum Islam, permohonan itsbat nikahyang diajukan sesuai dengan Pasal 2 ayat (2) Undang-Undang Nomor 1 Tahun 1974 tentang perkawinan dan Pasal 7 ayat (3) huruf (d) Kompilasi Hukum Islam, maka permohonan Pemohon patut untuk dikabulkan.

Ketentuan Pasal 2 ayat (2) Undang-Undang Nomor 1 Tahun 1974 tentang Perkawinan jo. Pasal 2 ayat (1) Peraturan Pemerintah Nomor 9 Tahun 1975 tentang Pelaksanaan Undang-Undang Nomor 1 Tahun 1974 Tentang perkawinan jo. Pasal 5 Ayat (1) Kompilasi Hukum Iskam, Majelis Hakim memandang perlu memerintahkan kepada Pemohon untuk mencatatkan perkawinannya kepada Pegawai Pencatat Nikah pada Kantor Urusan Agama yang mewilayahi tempat tinggalnya.

Penemuan hukum (rechtsvinding) pada dasarnya merupakan wilayah kerja hukum yang sangat luas cakupannya, ia dapat dilakukan oleh orang-perongan (individu), ilmuwan atau peneliti hukum, para penegak hukum (hakim, haksa, polisi dan pengacara atau advokat). Namun dalam diskursus penemuan hukum, lebih banyak dibicarakan pada upaya penemuan hukum oleh Hakim, pembentuk undang-undang dan peneliti hukum.Penemuan hukum oleh Hakim, tidak sematamata menyangkut penerapan peraturan-peraturan hukum terhadap peristiwa konkrit, tapi juga penciptaan hukum dan pembetukan hukumnya sekaligus. ${ }^{38}$

${ }^{38}$ Jazim Hamidi, Hermeneutika Hukum, (Yogyakarta: UII Press, 2005), hlm. 56. 
Hakim melakukan penemuan hukum, karena ia dihadapkan pada peristiwa konkrit atau konflik untuk diselesaikan, jadi sifatnya konfliktif. Hasil penemuan hukumnya merupakan hukum, karena mempunyai kekuatan mengikat sebagai hukum yang dituangkan dalam bentuk putusan.Hasil penemuan hukum oleh Hakim itu sekaligus merupakan sumber hukum juga.

Muhammad Busyro Muqaddas berpendapat bahwa dengan bertitik tolak dari berbagai pendapat mengenai arti penemuan hukum dapat dikemukakan bahwa, penemuan hukum dalam hal ini dilakukan oleh Hakim ada dua macam yaitu: pertama, penemuan hukum dalam arti penerapan suatu peraturan dalam suatu peristiwa konkrit, untuk peristiwa mana telah tersedia peraturannya secara jelas. Hal ini menunjukkan suatu metode yang lebih bersifat sederhana dalam arti bahwa hakim hanya sebatas pada menerapkan suatu aturan hukum (undangundang) yang sesuai dengan faktanya atau peristiwa konkritnya; kedua, penemuan hukum dalam arti pembentukan hukum, dimana untuk suatu peristiwa konkrit tidak tersedia suatu peraturannya yang jelas/lengkap untuk diterapkan.Dalam hal ini hakim tidak menemukan aturan hukumnya (undang-undangnya) yang sesuai dengan fakta atau peristiwa konkritnya, sehingga harus membentuknya melalui suatu metode tertentu. ${ }^{39}$

Dengan demikian, pada dasarnya penemuan hukum merupakan proses pembentukan hukum oleh subyek hukum atau pelaku penemuan hukum dalam upaya menerapkan peraturan hukum umum terhadap peristiwanya berdasarkan kaidah-kaidah atau metode tertentu yang dapat dibenarkan dalam ilmu hukum, seperti interpretasi, penalaran, eksposisi dan lain-lain. Kaidah-kaidah tersebut digunakan agar penerapan aturan hukumnya terhadap peristiwanya tersebut dapat dilakukan secara tepat dan relevan menurut hukum, sehingga hasil yang diperoleh dari proses tersebut juga dapat diterima dan dipertanggungjawabkan dalam ilmu hukum.

Metode metode argumentasi yang disebut juga dengan metode penalaran hukum, redenering atau reasoning. Metode ini dipergunakan apabila undangundangnya tidak lengkap, maka untuk melengkapinya dipergunakan metode argumentasi. Shidarta menyimpulkan setidaknya ada 6 langkah dalam penalaran hukum, yaitu:

a. Mengindentifikasi fakta-fakta untuk menghasilkan suatu struktur (peta) kasus yang sungguh-sungguh diyakini oleh hakim sebagai kasus yang riil terjadi.

b. Menghubungkan (mensubsumsi) struktutur kasusu tersebut dengan sumber-sumber hukum yang relevan, sehingga ia dapat menetapkan perbuatan dalam peristilahan yuridis (legal term)

c. Meyeleksi sumber hukum dan aturan hukum yang relevan untuk kemudian mencari tahu kebijakan yang terkandung di dalam aturan hukum itu (the police underlying those rules), sehingga dihasilkan suatu struktur (peta) aturan yang koheren.

${ }^{39}$ Muhammad Busyro Muqaddas sebagaimana dikutip Bambang Sutiyoso, Metode Penemuan Hukum Upaya Mewujudkan Hukum Yang Pasti dan Berkeadilan, (Jogyakarta: UII Press, 2002), hlm. 52. 
d. Menghubungkan struktur aturan dengan struktur aturan dengan struktur kasus.

e. Mencari alternatif-alternatif penyelesaian yang mungkin.

f. Menetapkan pilihan atas salah satu alternatif untuk kemudian di formulasikan sebagai putusan akhir. ${ }^{40}$

Salah satu metode dalam yang digunakan dalam argumentasi tersebut yaitu metode a contrario (argumentum a contrario) yaitu merupakan cara menjelaskan makna undang-undang dengan didasarkan pada pengertian yang sebaliknya dari peristiwa konkrit yang dihadapi dengan perisstiwa dengan peristiwa yang diatur dalam undang-undang. Apabila suatu peristiwa tertentu diatur dalam undangundang, tetapi peristiwa lainnya yang mirip tidak, maka berlaku hal yang sebaliknya. $^{41}$

Metode ini memberikan kesempatan pada hakim untuk menemukan hukum dengan mempertimbangkan bahwa apabila undang-undangmenetapkan hal-hal tertentu untuk peristiwa tertentu, maka peraturan terbatas itu pada peristiwa tertentu itu dan untuk peristiwa di luarnya berlaku kebalikannya. Jadi esensinya mengedepankan cara penafsiran yang berlawanan pengertian antara peristiwa konkret yang dihadapi dengan peristiwa yang diatur dalam undang-undang. Pada metode argumentum a contrario ini titik berat diletakkan pada ketidak samaan peristiwanya.Di sini diperlukan segi negatif dari undang-undang. ${ }^{42}$

Berdasarkan metode penemuan sebagaimana yang diuraikan di atas maka Hakim Mahkamah Syar'iyah Bireuen dalam memutus perkara itsbat nikah yang menerima keterangan saksi testimonium de aditu menggunakan metode a contrario (argumentum a contrario), karena dalam hal ini Hakim menyimpangi aturan Pasal 171 HIR dan pasal 1907 kitab Undang-Undang Hukum Perdata yaitu "Keterangan yang diberikan harus berdasarkan sumber pengetahuan yang jelas. Dan sumber pengetahuan yang dibenarkan hukum mesti merupakan pengalaman, penglihatan atau pendengaran yang bersifat langsung dari peristiwa atau kejadian yang berhubungan dengan pokok perkara yang disengkatan para pihak". Penyimpangan tersebut sangat beralasan karena saksi utama yang mengetahui kejadian pernikahan sudah tidak ada lagi, sehingga apabila menerapkan ketentuan Pasal 171 HIR dan 1907 kitab Undang-Undang Hukum Perdata tersebut maka tidak ada solusi yang dapat diambil dalam menyelesaikan perkara isbat nikah.

Berdasarkan pertimbangan-pertimbangan Hakim Mahkamah Syar'iyah Bireuen sebagaimana dalam putusan-putusan yang telah diuraikan di atas apabila dikaitkan dengan pendapat shidarta mengenai langkah-langkah yang ditempuh dalam metode penalaran hukum, maka apa yang telah diterapkan hakim telah sesuai, dengan alasan sebagai berikut:

1. Hakim telah mengindentifikasi fakta-fakta untuk menghasilkan suatu struktur (peta) kasus yang sungguh-sungguh diyakini oleh hakim sebagai kasus yang riil terjadi yaitu tidak ada lagi saksi-saksi yang mengetahui

${ }^{40}$ Bambang Sutiyoso, Metode Penemuan Hukum Upaya Mewujudkan Hukum Yang Pasti dan Berkeadilan, (Jogyakarta: UII Press, 2002), hlm. 135

${ }^{41}$ Ibid. hlm. 139.

${ }^{42}$ Sudikno Mertokusumo dan A. Pitlo, Bab-bab Tentang Penemuan Hukum, (Citra Aditya Bakti: Bandung, 2003), hlm. 26. 
secara langsung peristiwa nikah karena peristiwa nikah tersebut sudah sangat lama terjadi, sedangkan berita mengenai adanya pernikahan para Pemohon itsbat nikah sudah menyebar luas di masyarakat dan tidak ada masyarakat yang membantah atau menggugat pernikahan tersebut.

2. Hakim telah menghubungkan (mensubsumsi) struktutur kasus tersebut dengan sumber-sumber hukum yang relevan, sehingga ia dapat menetapkan perbuatan dalam peristilahan yuridis (legal term), yaitu dengan menghubungkan kasus saksi-saksi yang tidak mengetahui secara langsung peristiwa nikah tersebut kepada aturan mengenai syarat materiil saksi sehingga keterangan tersebut dapat disimpulkan sebagai testimonium de auditu.

3. Hakim telah meyeleksi sumber hukum dan aturan hukum yang relevan untuk kemudian mencari tahu kebijakan yang terkandung di dalam aturan hukum itu (the police underlying those rules), sehingga dihasilkan suatu struktur (peta) aturan yang koheren, yaitu Hakim telah menyeleksi doktrin-doktrin hukum yaitu pendapat para ulama dalam kitab-kitab fikih yang membolehkan pemakaian testimonium de auditu/saksi istifadhah dalam perkara pernikahan.

4. Hakim telah Menghubungkan struktur aturan dengan dengan struktur kasus, yaitu dengan mengkorelasikan doktrin-doktrin fikih dan doktrin hukum lain terhadap kasus saksi testimonium de auditu dalam parkara itsbat nikah.

5. Hakim telah mencari alternatif-alternatif penyelesaian yang mungkin dalam perkara itsbat nikah dengan kesaksian testimonium de auditu yaitu dengan mempertimbangkan adanya pengecualian (eksepsional) dapat menerima saksi testimonium de auditu terhadap perkara itsbat nikah yang sudah lama terjadi dan tidak ada lagi saksi utama yang mengetahui secara langsung pernikahan tersebut.

6. Hakim telah menetapkan pilihan atas salah satu alternatif untuk kemudian di formulasikan sebagai putusan akhir yaitu dengan menjadikan fakta keterangan saksi testimonium de auditu tersebut sehingga dapat menguatkan dalil permohonan Pemohon dan karena itu pula maka permohonan Pemohon dikabulkan.

Berdasarkan analisis tersebut maka dapat disimpulkan bahwa apa yang diterapkan oleh hakim Mahkamah Syar'iyah Bireuen dalam putusannya yang menerima keterangan saksi testimonium de auditudalam perkara itsbat nikah telah dilakukan secara tepat dan relevan menurut hukum, sehingga hasil yang diperoleh dari proses tersebut juga dapat diterima dan dipertanggungjawabkan dalam ilmu hukum.

Salah satu metode penemuan hukum dalam sistem hukum Islam adalah metode penetapan hukum melalui maqashid syari'ah, yang menegaskan bahwa hukum Islam disyari'atkan untuk mewujudkan dan memelihara maslahat umat manusia.Konsep ini telah diakui oleh para ulama dan oleh karena itu mereka memformulasikan suatu kaidah yang cukup populer,"Di mana ada maslahat, di 
sana terdapat hukum Allah. ${ }^{43}$ Teori maslahat di sini menurut Masdar F. Masudi sama dengan teori keadilan sosial dalam istilah filsafat hukum. ${ }^{44}$ Mashlahat berasal dari kata al-shulh atau al-islah yang berarti damai dan tentram.Damai berorientasi pada fisik sedangkan tentram berorintasi pada psikis. ${ }^{45}$

Inti dari konsep maqasid al-syariah adalah untuk mewujudkan kebaikan sekaligus menghindarkan keburukan atau menarik manfaat dan menolak mudharat, istilah yang sepadan dengan inti dari maqasid al-syari'ah tersebut adalah maslahat, karena penetapan hukum dalam Islam harus bermuara kepada maslahat.Untuk memahami hakikat dan peranan maqasid al-syari'ah.

Pembahasan tentang maqasid al-syari'ah secara khusus, sistematis dan jelas dilakukan oleh Abu Ishaq al-Syatibi dari kalangan Malikiyah, yang pada periode berikutnya lebih dikenal sebagai perumus teori ini. ${ }^{46}$ Dalam kitabnya alMuwafaqat yang sangat terkenal itu, al- Syatibi menghabiskan lebih kurang sepertiga pembahasannya mengenai maqashid al-syari'ah.Sudah tentu, pembahasan tentang maslahat pun menjadi bagian yang sangat penting dalam tulisannya.Ia secara tegas mengatakan bahwa tujuan utama Allah menetapkan hukum-hukum-Nya adalah untuk terwujudnya maslahat hidup manusia, baik di dunia maupun di akhirat. Karena itu, taklif dalam bidang hukum harus mengarah pada dan merealisasikan terwujudnya tujuan hukum tersebut. ${ }^{47}$ Seperti halnya ulama sebelumnya, ia juga membagi urutan dan skala prioritas maslahat menjadi tiga urutan peringkat, yaitu daruriyat, hajiyat, dan tahsiniyat.Yang dimaksud maslahat menurutnya seperti halnya konsep al-Ghazali, yaitu memelihara lima hal pokok, yaitu: agama, jiwa, akal, keturunan dan harta. ${ }^{48}$

Menilik kepada teori maqashid al-syari'ah tersebut yang kemudian dikorelasikan dengan putusan hakim Mahkamah Syar'iyah Bireuen yang menerima saksi testimonium de aditu dalam perkara itsbat nikah, maka menurut penulis pertimbangan hakim Mahkamah Syar'iyah Bireuen telah memenuhi asas maslahat dan telah menerapkan konsep maqashid al-syari'ah dalam menukan hukum, karena dengan putusan tersebut status hukum mengenai pernikahan seseorang menjadi jelas, sehingga salah satu tujuan keberlakuan hukum dalam Islam yaitu untuk memelihara keturunan telah terpenuhi.

Bandingkan jika hakim tidak fleksibel dengan memberlakukan ketentuan pembuktian yang melarang untuk menerima keterangan de a ditu sehingga permohonan itsbat nikah tersebut akan di ditolak, hal tersebut tentunya sebuah kemaslahatan bagi hakim karena telah menerapkan aturan pembuktian pada perkara yang ditanganinya, akan tetapi menimbulkan mafsaadat (kerugian) bagi pemohon isbat nikah, karena semua akibat hukum dari pernikahan, seperti adanya

\footnotetext{
${ }^{43}$ Muhammad Sa'id Ramdan al-Buti, Dawabit al-Maslahah fi al-Syariah al-Islamiyah, (Beirut, Mu'assasah ar-Risalah, 1977), hlm. 12.

${ }^{44}$ Masdar F. Mas'udi, "Meletakkan Kembali Maslahat Sebagai Acuan Syari'ah", Jurnal Ilmu dan Kebudayaan Ulumul Qur'anNo. 3, Vol. VI Tahun. 1995, hlm. 97.

${ }^{45}$ Jaih Mubarok, Sejarah dan Perkembangan Hukum Islam, (Bandung, PT. Remaja Roskadarya, 2003), hlm. 7.

${ }^{46}$ Hamka Haq, Filsafat Ushul Fiqh,( Makassar: Yayasan Al-Ahkam, 1998), hlm. 68. hlm. 4.

${ }^{47}$ Al-Syatibi, al-Muwafaqat fi Usul al-Syari'ah, Juz II, Mustafa Muhammad, Kairo, t.t., ${ }^{48}$ Ibid.
} 
hubungan hukum antara para Pemohon sebagai suami isteri, hubungan hukum antara para Pemohon dengan anak-anaknya, status harta bersama, hubungan waris mewarisi dan lain sebagainya telah terabaikan bahkan dianggap tidak ada, kemudian tidak ada solusi hukum lain yang dapat ditempuh oleh pihak-pihak setelah penolakan oleh hakim tersebut. Hal ini tidak sejalan dengan konsep maqashid al-syari'ah dalam penerapan hukum, selain itu tidak sejalan pula dengan salah satu kaidah fikih:

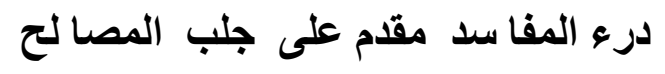

Artinya: "Menghindarkan mafsadat harus lebih diutamakan daripada meraihmaslahat"،49

Putusan hakim Mahkamah Syar'iyah yang menerima saksi testimonium de aditu dalam perkara itsbat nikah telah memenuhi asas kepastian hukum, tentunya kepastian hukum dalam hal ini ialah adanya legalitas terhadap keabsahan pernikahan yang tidak tercatat dari masyarakat pencari keadilan, karena Menurut Gustav Radbruch, hukum harus mengandung 3 (tiga) nilai identitas, yaitu sebagai berikut : ${ }^{50}$

1. Asas kepastian hukum(rechtmatigheid). Asas ini meninjau dari sudut yuridis.

2. Asas keadilan hukum (gerectigheit). Asas ini meninjau dari sudut filosofis, dimana keadilan adalah kesamaan hak untuk semua orang di depan pengadilan

3. Asas kemanfaatan hukum (zwechmatigheid atau doelmatigheid atau utility).

Hakim harus mengadili menurut hukum.Oleh karena itu putusannya harus berdasarkan hukum, harus mengandung dan menjamin kepastian hukum, yang berarti bahwa ada jaminan bahwa hukum dijalankan, bahwa yang berhak menurut hukum dapat memperoleh haknya dan bahwa putusannya dilaksanakan.Juga bahwa perkara yang serupa harus diputus serupa pula.

Disamping itu putusan Hakim harus bermanfaat, baik bagi yang bersangkutan maupun bagi masyarakat.Masyarakat dalam hal ini berkepentingan, karena masyarakat menginginkan adanya keseimbangan tatanan dalam masyarakat.Dengan adanya sengketa maka keseimbangan di dalam masyarakat itu terganggu, dan keseimbangan yang terganggu itu harus dipulihkan kembali.Lebih dari itu yang tidak kurang penting ialah, bahwa putusan harus adil, adil dirasakan oleh pihak yang bersangkutan; meskipun pihak lawan menilainya tidak adil, maka masyarakat harus dapat menerimanya sebagai keadilan.

Dalam usaha menemukan hukum, majelis hakim dapat mencarinya di dalam kitab-kitab fiqih dan perundang-undangan sebagai hukum tertulis, sementara

\footnotetext{
${ }^{49}$ Ahmad Sabiq bin Abdul Lathif Abu Yusuf, Kaidah-Kaidah Praktis Memahami Fiqih Islam (Qowaid Fiqhiyyah), (Gresik:Pustaka al-Furqon, 2013), hlm.. 101

${ }^{50}$ http://hukum.kompasiana.com. "Keadilan dari Dimensi Sistem Hukum", diakses pada tanggal 20 Juli 2016.
} 
kepala adat dan penasehat agama sebagai hukum tidak tertulis. Sedangkan yurisprudensi merupakan putusan hakim terdahulu dengan permasalahan yang sama yang sering diikuti dan dijadikan dasar dalam penetapan hukum oleh hakim sekarang dan karya ilmiah dari pakar hukum yang ada sangkut pautnya dengan perkara yang ditangani tersebut.

Apabila majelis hakim tidak menemukan hukum melalui sumber-sumber sebagaimana dikemukakan di atas, maka majelis hakim mencarinya melalui metode interpretasi dan kontruksi. Dalam hal ini majelis hakim tidak boleh menolak perkara yang diajukan dengan alasan tidak ada hukumnya, sebagaimana dijelaskan di dalam Pasal 10 ayat 1 Undang-Undang Nomor 49 Tahun 2009 Tentang Kekuasaan Kehakiman. Seperti dalam perkara itsbat nikah ada satu saksi, dimana kesaksiannya tidak melihat dan mendengar sendiri melainkan dari cerita orang tua saksi dan orang tua atau orang lain.

Dalam bahasa hukum kesaksian de auditu sebenarnya bukanlah keterangan saksi dan tidak mempunyai nilai pembuktian, akan tetapi menurut Buku II edisi revisi Pedoman Pelaksanaan Tugas dan Administrasi Peradilan Agama tahun 2013 yang diambil alih sebagai pendapat majelis hakim bahwa testimonium de auditu dapat dijadikan sumber persangkaan. Untuk itu, majelis hakim akan mempertimbangkannya apakah keterangan saksi-saksi tersebut dapat dijadikan sumber persangkaan sesuai dengan Pasal 130 Rbg joPasal 1915 dan 1921 KUHPerdata.

Dalam perkara itsbat nikah, majelis hakim juga mempertimbangkan kenapa saksi de auditu dibolehkan.Pembolehan testimonium de auditu dalam perkara itsbat nikah adalah sepanjang tidak ada bukti yang melawan, dan sepanjang tidak ada bukti sebaliknya.Oleh karena itu, testimonium de auditu yang tidak bersumber dari aslinya, maka jika ada yang membuktikan sebaliknya testimonium de auditu tidak berlaku lagi.Atau bahkan keberadaannya bisa menjadi bukti yang berdiri sendiri dan bukan bukti tambahan.

Selanjutnya majelis hakim dalam memberikan pertimbanganya guna memperkuat pembuktian dalam perkara ini, menggambil dasar hukum dari fiqih sunnah jillid 3 halaman 426 dan kitab I'anatut thalibin juz 4 halaman 245 dan 301. Dari pemaparan pertimbangan hukum di atas penulis berpendapat bahwa majelis hakim sudah tepat dengan berlandaskan kitab fiqih sunnah, ketika melihat ada saksi dengan kesaksian de auditu yang kesaksianya tidak melihat dan mendengar sendiri dan seharusnya ditambah dengan Pasal-Pasal persangkaan agar tidak berbenturan dengan Pasal 171 HIR sampai 176 RBg dan Pasal 308 dan 309 $\mathrm{RBg}$.

Dari pemaparan di atas dapat disimpulkan bahwa landasan hukum yang digunakan oleh majelis hakim dalam memeriksa dan membuat putusan, yaitu:

(a). Pasal 163 HIR menyatakan mengenai yang mempunyai suatu hak, maka harus membuktikan adanya hak atau peristiwa di depan persidangan.

(b). Pasal 170, 171, dan 172 HIR yang menyatakan saksi harus mengalami dan mengetahui sendiri secara langsung kejadiannya.

(c). Pasal 7 ayat 3 huruf (d) dan (e) menjelaskan bahwa itsbat nikah yang dapat diajukan di Pengadilan Agama/Mahkamah Syar'iyah terbatas mengenai adanya perkawinan sebelum berlakunya Undang-Undang 
Nomor 1 Tahun 1974 dan tidak mempunyai halangan menurut UndangUndang Nomor 1 Tahun 1974.

(d). Pasal 7 ayat (4) Kompilasi Hukum Islam, yang berhak mengajukan permohonan itsbat nikah ialah suami atau isteri,anak-anak mereka, wali nikah dan pihak yang berkepentingan dengan perkawinan itu.

(e). Kitab I'anatut thalibin juz IV halaman 254 pernikahan yang sudah tersiar (dari orang banyak yang tidak mungkin mereka semua berdusta) walaupun ia (saksi) dari golongan sedarah ataupun seqabilah (suku) dengan syarat tidak ada yang melawanya.

(f). Kitab Fiqih Sunnah jilid III halaman 426 tentang kesaksian istifadhah.

(g). Pasal 14 sampai 38 Kompilasi Hukum Islam tentang pemenuhan syarat dan rukun pernikahan.

(h). Ketentuan hukum dan doktrin Hukum Islam (pendapat ahli fikih), sesuai dengan Pasal 2 ayat (2) Undang-Undang Nomor 1 Tahun 1974 tentang perkawinan dan Pasal 7 ayat (3) huruf (d) Kompilasi Hukum Islam.

(i). Pasal 2 ayat (1) Undang-Undang Nomor 1 Tahun 1974 tentang perkawinan menyatakan perkawinan adalah sah apbila dilakukan menurut hukum masing-masing agama dan kepercayaan.

(j). Pasal 2 ayat (2) Undang-Undang Nomor 1 Tahun 1974 tentang Perkawinan jo. Pasal 2 ayat (1) Peraturan Pemerintah Nomor 9 Tahun 1975 Tentang Pelaksanaan Undang-undang Nomor 1 Tahun 1974 tentang perkawinan jo. Pasal 5 Ayat (1) Kompilasi Hukum Islam, Pasal 89 ayat 1 Undang-Undang Nomor 7 Tahun 1989 sebagaimana perubahan pertama dengan Undang-Undang Nomor 3 Tahun 2006 dan perubahan kedua dengan Undang-undang Nomor 50 Tahun 2009 bahwa segala biaya yang timbul dalam perkara ini dibebankan kepada Pemohon.

Berdasarkan penjelasan di atas dapat dipahami bahwa tugas dan peran hakim untuk mencari kebenaran formil adalah tidak cukup hanya bersifat pasif namun harus aktif argumentatif karena tujuan dan fungsi peradilan adalah untuk menegakkan kebenaran dan keadilan. Penerapan Saksi testimonium de auditu khususnya di Mahkamah Syar'iyah Bireuen tidak otomatis ditolak sehingga tidak ada nilainya sama sekali, hakim Mahkamah Syar'iyah Bireuen menerimanya sebagai alat bukti dengan menganalisis dasar eksepsional (pengecualian) pada perkara itsbat nikah yang tidak ada lagi saksi utama mengetahui secara langsung pernikahan yang telah dilaksanakan. Hakim Mahkamah Syar'iyah Bireuen telah mempertimbangkan hal tersebut sesuai dengan kaidah penemuan hukum, sehingga telah terpenuhinya nilai-nilai hukum yang dicita-citakan dalam putusan hakim. Cita-cita hukum tersebut antara lain adanya kepastian hukum(rechtmatigheid), adanya keadilan hukum (gerectigheit) dan adanya kemanfaatan hukum (zwechmatigheid atau doelmatigheid atau utility). Selain dari pada itu banyak maslahat yang dicapai pada putusan hakim tersebut. 


\section{Kesimpulan}

Berdasarkan uraian di atas maka dapat disimpulkan bahwa, prosedur pembuktian saksi testimonium de auditu dalam perkara itsbat nikah di Mahkamah Syar'iyah Bireuen sama dengan pemeriksaan saksi-saksi lainnya. Mahkamah Syar'iyah Bireuen akan memeriksa syarat formil dan materil untuk membuat penetapan permohonan diterima atau tidak. Majelis hakim atau ketua hakim menanyakan kepada saksi tentang identitas yang meliputi nama, umur, pekerjaan, tempat tinggal, hubungan saksi dengan para pihak, dan apakah ada hubungan keluarga, perkawinan ataupun hubungan kerja, setelah itu semua di periksa seperti biasa mulai dari sumpah saksi sampai keterangan saksi dikonfirmasi terlebih dahulu kepada para pihak. Selain daripada itu, penerapan saksi testimonium de auditu dalam perkara itsbat nikah di Mahkamah Syar'iyah Bireuentidak otomatis ditolak sehingga tidak ada nilainya sama sekali, karenadapat diterima sebagai alat bukti dengan menganalisisdasar eksepsional untuk dapat diterimanya dengan mempertimbangkan sejauh mana kualitas dan nilai kekuatan pembuktiannya yang melekat pada keterangan saksi de auditu tersebut. Dasar penerimaannya dengan mengambil alih beberapa sumber hukum yang digunakan oleh majelis hakim dalam memeriksa dan membuat putusan baik dalam hukum perdata maupun hukum Islam, diantaranya; Pasal 163 HIR, Pasal 170, 171, dan 172 HIR, Pasal 7 ayat 3 huruf (d) dan (e), Undang-Undang Nomor 1 Tahun 1974, Pasal 7 ayat (4) Kompilasi Hukum Islam, kitab I'anatut thalibin juz IV halaman 254, kitab fiqih sunnah jilid III halaman, dan Pasal 14 sampai 38 Kompilasi Hukum Islam.

\section{DAFTAR PUSTAKA}

\section{A. Buku}

Amirin, Tatang M. Menyusun Rencana Penelitian, Cet. III, Jakarta: Rajawali, 1990.

Aripin, Jaenal.Peradilan Agama dalam Bingkai Reformasi Hukum di Indonesia, Jakarta: Kencana, 2008.

Fajar ND, Mukti dan Yulianto Achmad. Dualisme Penelitian Hukum Normatif dan Hukum Empiris, Jakarta: Pustaka Pelajar, 2010.

Harahap, M. Yahya Hukum Acara Perdata: Gugatan, Persidangan, Penyitaan, Pembuktian dan Putusan Pengadilan, Jakarta: Sinar Grafika, 2005.

Harahap, M. Yahya. Kedudukan Kewenangan dan Acara Peradilan Agama: Undang-undang No. 7 Tahun 1989, Cet. II, Jakarta: Pustaka Kartini, 1993.

Mertokusumo,Sudikno.Hukum Acara Perdata Indonesia, Yogyakarta: Liberty, 1988.

Muhammad, Abdulkadir. Hukum dan Penelitian Hukum, Bandung: Citra Aditya Bakti, 2004.

Mulyadi, Lilik. Hukum Acara Perdata Menurut Teori dan Praktek Peradilan Indonesia, Jakarta: Djambatan, 1999.

Ramulyo, Idris Mohd. Hukum Perkawinan Islam: Suatu Analisis UU No. 1 Tahun 1974 dan KHI, Jakarta: Bumi Aksara, 1996.

Rasyid, Roihan. Hukum Acara Peradilan Agama, Jakarta: Rajawali, 1991. 
Sabiq, Sayyid. Fiqih Sunnah, Jilid 3, Bairut: Dar al-Fikr, 1983.

Soesilo, R..RIB/HIR dengan Penjelasan, Bogor: Politeia, 1995.

Sunggono, Bambang (I), Penelitian Hukum: Suatu Pengantar, Jakarta: Raja Grafindo Persada, 2002.

Syahlani, Hensyah. Pembuktian dalam Beracara Perdata \& Teknis Penyusunan Putusan Pengadilan Tingkat Pertama, tp,: tt, 2007.

\section{B. Tesis /Jurnal/Skripsi/Makalah/Artikel/Majalah/Koran}

Badan Pusat Statistik Kabupaten Bireuen, Bireuen Dalam Angka, BPS Bireuen, 2012.

Syahrin, Alvi. Pengaturan Hukum dan Kebijakan Pembangunan Perumahan dan Pemukiman Berkelanjutan, Medan: Pustaka Bangsa Press, 2003.

\section{Peraturan Perundang-Undangan}

Kitab-Kitab Hukum Perdata (Burgerlijk Wetboek), diterjemahkan oleh Subekti dan R. Tjitrosudibio, Jakarta: Pradnya Paramita, 2008.

Undang-Undang Nomor 7 Tahun 1989 tentang Peradilan Agama.

Undang-undang Perkawinan Republik Indonesia Nomor 1 Tahun 1974, Cet. II, Surabaya: Tinta Mas, 1990. 